\title{
CHARACTERISTICS OF FARMER ADOPTERS OF HIGH VALUE HORTICULTURAL CROPS IN INDONESIA
}

\author{
Suprehatin*)1 \\ *) Center for Agriculture and Rural Development Studies, IPB University \\ Jl Raya Pajajaran Kampus IPB Baranangsiang, Bogor 16129
}

\begin{abstract}
Improving the participation of smallholder farmers in horticultural value chains to benefit from the rapidly growing demand for high value agricultural products is one strategy for raising farm income. However, smallholder farmer adoption of high value horticultural crops in Indonesian is under-researched. To address this knowledge gap, this study aims to examines the characteristics of farmers who adopted and those who did not adopt a new horticultural crop with respect to the household (farmer), farm and institutional characteristics. The unique data from a 2013 survey of 960 Indonesian farmers on Java Island that produce a variety of agricultural products was analysed using independent-sample t-tests. Basic statistical analysis showed relatively low adoption rates $(10 \%)$ of new horticultural crops amongst 960 selected Indonesian farmers with different characteristics. The result showed that current low rates of horticultural crop adoption are associated with a variety of factors, such as lower levels of education among farmers, resource constraints, lack of information on horticultural crop production and low participation in farmer groups.
\end{abstract}

Keywords: horticultural crops, smallholder farmer adoption, household

\begin{abstract}
Abstrak: Meningkatkan partisipasi petani kecil dalam rantai nilai hortikultura merupakan salah satu strategi untuk meningkatkan pendapatan petani. Hal ini dikarenakan partisipasi pada rantai nilai hortikultura berpotensi mendapatkan keuntungan dari permintaan produk hortikultura bernilai tinggi yang saat ini terus meningkat. Meskipun demikian, penelitian terkait adopsi petani skala kecil terhadap tanaman hortikultura bernilai tinggi di Indonesia masih terbatas. Berdasarkan hal tersebut, penelitian ini bertujuan menganalisis karakteristik petani yang mengadopsi dan mereka yang tidak mengadopsi tanaman hortikultura baru berdasarkan tiga karakteristik rumah tangga (petani), usahatani dan kelembagaan. Penelitian ini menggunakan data unik dari survei terhadap 960 petani Indonesia di Pulau Jawa pada tahun 2013 dan dianalisis menggunakan uji-t sampel independen. Analisis statistik deskriptifmenunjukkan bahwa tingkat adopsi petani responden terhadap tanaman hortikultura baru relatif rendah (10\%) dengan karakteristik yang berbeda. Hasil penelitian menunjukkan bahwa tingkat adopsi tanaman hortikultura baru yang rendah saat ini berkaitan dengan berbagai faktor, seperti tingkat pendidikan petani yang relatif rendah, kendala sumber daya, kurangnya informasi tentang produksi tanaman hortikultura dan rendahnya partisipasi dalam kelompok tani.
\end{abstract}

Kata kunci: tanaman hortikultura, adopsi petani kecil, rumah tangga

\footnotetext{
${ }^{1}$ Corresponding author:

Email: suprehatin@apps.ipb.ac.id
} 


\section{INTRODUCTION}

Indonesia is experiencing an agricultural food market transformation, with rapidly growing demand for high value agricultural products (Daryanto et al. 2015; Reardon et al. 2015; Reardon et al. 2014), including livestock products such as meat and dairy products and horticultural products such as fruits and vegetables. Currently, Indonesian consumers are demanding more those high value agricultural products, which indicates that diets of Indonesian consumers are becoming more diversified (Minot et al. 2015; Reardon et al. 2014). The rapid increase in high value agricultural products is driven by economic growth, urbanisation and demographic change in Indonesia (Reardon et al. 2015; Reardon et al. 2014). In addition, this rapid transformation has also been driven by emerging modern retail markets in Indonesia including minimarkets and supermarkets (Reardon et al. 2014; Minot et al. 2015; Toiba et al. 2015).

Given this rapid transformation, promoting smallholder farmer participation in higher value horticultural chains to improve their livelihoods has become an important policyrecommendation, including in Indonesiancontext. Horticultural crops may more profitable for farmers and may offer more lucrative market opportunities (Roy \& Thorat, 2008; Schipmann \& Qaim, 2009). There are wide range of potential benefits of promoting horticultural crop adoption among smallholder farmers both in the national and household levels. First, production of horticultural crops offers potential widespread benefits for Indonesia, which address national food security by addressing aspects such as access and availability of nutritious food (Babatunde \& Qaim, 2010). Second, horticultural crops provide potential benefits in terms of jobs creation in the community as horticultural crops are more labour intensive than other staple food crops such as rice (Joshi et al. 2006). In addition, horticultural crops provide sources of important micronutrients, such as vitamins and minerals (Hughes \& Keatinge, 2012; Virchow et al. 2015).

However, Indonesian smallholder farmers' participation in horticultural value chains remains low. Low participation rates raise concerns regarding whether Indonesian smallholder farmers are constrained from diversifying their production systems into horticultural crops. In addition, the dynamics of farmer adoption of horticultural crops in Indonesian context is under- researched. The broad literature on agricultural technology adoption has suggested key socio-economic characteristic influence adoption of agricultural technology. These characteristics include household (farmer), farm and institutional characteristics such as human capital, household assets, financial capital, production practice and income (Doss, 2006; Feder et al. 1985; Foster \& Rosenzweig, 2010; Jack, 2011; Knowler \& Bradshaw, 2007). Thus, identifying socioeconomic characteristics of smallholder farmers would be useful in identifying strategies to facilitate technology adoption among them. Examining fam household characteristics also provides a better understanding of horticultural crop adoption by smallholder farmers.

To address this knowledge gap, this study aims to examine the current practices of horticultural crop adoption in Indonesia and highlighted the characteristics of farmers who adopted and those who did not adopt a new horticultural crop with respect to the farm household, farm and institutional characteristics. The remainder of this paper is structured as follows: Section 2 provides an overview of the household survey data collected in Indonesia and methods; this is followed by the results and discussion of results in Section 3. The summary and conclusion are presented in the final section.

\section{METHODS}

This study uses the survey data of Indonesian farmer households. A stratified random sample of 960 farmers was drawn from 96 villages across six districts in Java island: Subang, Tasikmalaya, Demak, Rembang, Tulungagung and Jombang (Suprehatin, 2015). The random sample included farmers that produce a variety of agricultural crops including data of farmers that have adopted new horticultural crops. Basic descriptive statistical analyses, including frequencies and means, were used to describe the current practices of new horticultural crop adoption in Indonesia. This analysis covered rate of adoption and dynamics of adoption of new horticultural crops.

An independent samples t-test was used to compare sample means of adopters and non-adopters with respect to household and farm characteristics, institutional and income sources. A Two-sample t-test was used to test whether means were statistically different between 
adopters and non-adopters (where we are testing $\mathrm{H}_{0}$ : $\mu_{1}-\mu_{2}=0$ versus $\mathrm{Ha}=\mu_{1}-\mu_{2} \neq 0$, where $\mu_{1}$ is the sample mean of adopters and $\mu_{2}$ is the sample mean of nonadopters) (Black, 2009).

This study used respondents answers to the question "Did you start growing any crop for the first time since 2007?" to classify farmers into new horticultural crop adopters and non-adopters. Therefore, farmers who adopted a new horticultural crop between 2007 and 2012 were classified as 'adopters', while farmers who did not adopt new crops in that period were considered 'non-adopters'. Based on that classification, 101 farm households were classified as adopters and 859 farm households as non-adopters.

\section{RESULTS}

This section presents the results of the comparative analysis of the adopters of new horticultural crop versus non-adopters in Indonesia. This discusses differences between adopters and non-adopters in terms of farmer and farm characteristics, institutional factors and sources of income. As mentioned earlier, the two-sample t-test was used to examine differences in mean values among adopters and non-adopters. These characteristics were expected to provide insight to why a specific farmer adopted new horticultural crops.

\section{Household Characteristics}

Household characteristics that are often determinants of agricultural technology adoption are human capital, assets and location (Feder et al. 1985). Table 1 presents these household characteristics and results of a difference test using the two-sample t-test on the variables.

First, in terms of human capital, the average age of all respondents was 51 years (Table 1). This is parallel to the current national agricultural census (Sensus Pertanian) data, which shows that $28 \%$ of farmers are aged between 45 and 54, 26\% (between 35-44), 20\% (between 55-64), 13\% (above 64), 12\% (between 25-34) and 1\% (below 25) (BPS, 2013). On average, both adopting and non-adopting head of households completed primary school. All farm households in the two groups had a relatively similar number of household members aged between 15 and 65 years. The number of family members indicates availability of family labour that can be devoted to agricultural farming.

The main significant differences in the two groups were that farm household heads of new horticultural crop adopters and their spouses had significantly higher education than non-adopters, horticultural crop adopting farmers were also significantly younger on average. Furthermore, most adopters were experienced horticultural farmers. This means that higher levels of education and practical horticultural farming experience can be considered important factors influencing adoption of high value horticultural crops. While most household heads were literate (could read and write), the spouses of adopters' had better literacy rates than non-adopters' spouses. This difference in literacy level may help improve spouses', who were in most cases women, understanding of new technologies including new horticultural crops.

Second, in terms of assets, most farm households had access to regular electricity and water (Table 1). There were also similarities in terms of value of transportation and production assets between new horticultural crop adopters and non-adopters. The main difference was that most adopter households had access to a communication device or applications associated with information and communication technologies (ICTs), particularly mobile phone and Internet access. This suggests that ICTs may assist households to obtain access to information needed to produce new horticultural crops. Adopters also had higher value of storage assets for post-harvest activities of horticultural products, such as drying, sorting and grading.

Third, in terms of location, both adopters and nonadopters of new horticultural crops had similar access to asphalt roads and local markets (Table 1). The main differences between the two groups were that most adopter households live in higher-level land areas (on average 293 metres) and were located further from urban markets (on average $23.35 \mathrm{~km}$ ). This finding is in line with highland areas favouring horticultural crop production (Midmore \& Poudel, 1996; Poudel et al. 1998). 
Table 1. Comparison of household (and farmer) characteristics for adopters and non-adopters of new horticultural crops

\begin{tabular}{|c|c|c|c|c|}
\hline \multirow{2}{*}{ Household Characteristics } & $\begin{array}{l}\text { All Samples } \\
\quad(\mathrm{n}=960)\end{array}$ & $\begin{array}{l}\text { Non-adopters } \\
\quad(\mathrm{n}=859)\end{array}$ & $\begin{array}{l}\text { Adopters } \\
(\mathrm{n}=101)\end{array}$ & \multirow{2}{*}{$\operatorname{Diff}^{1}$} \\
\hline & Mean & Mean & Mean & \\
\hline \multicolumn{5}{|l|}{ Human capital } \\
\hline Age of household head (years) & 51.69 & 52.10 & 48.26 & $3.84 * * *$ \\
\hline Education of household head (years) & 7.21 & 7.10 & 8.12 & $-1.02 * * *$ \\
\hline Age of spouse (years) & 42.05 & 42.17 & 41.04 & 1.13 \\
\hline Education of spouse (years) & 6.59 & 6.48 & 7.56 & $-1.09 * * *$ \\
\hline$\%$ of HH can read & 0.97 & 0.97 & 0.98 & -0.01 \\
\hline$\%$ of spouse can read & 0.89 & 0.89 & 0.96 & $-0.07 * *$ \\
\hline$\%$ of HH can speak Bahasa & 0.97 & 0.97 & 0.99 & -0.02 \\
\hline$\%$ of spouse can speak Bahasa & 0.89 & 0.88 & 0.96 & $-0.08 * *$ \\
\hline Household size & 3.78 & 3.75 & 4.09 & $-0.34 * *$ \\
\hline Number of children aged under 15 & 0.69 & 0.65 & 1.06 & $-0.41 * * *$ \\
\hline Number of adults aged between $16 \& 65$ & 2.69 & 2.69 & 2.67 & 0.02 \\
\hline$\%$ of household engaged horticultural crops in 2007 & 0.40 & 0.37 & 0.61 & $-0.24 * * *$ \\
\hline \multicolumn{5}{|l|}{ Assets } \\
\hline Area of house, including yard area (ha) & 0.04 & 0.04 & 0.04 & 0.00 \\
\hline Value of house (million Rp) & 134.28 & 134.81 & 129.77 & 5.05 \\
\hline$\%$ of household with own house & 0.99 & 0.99 & 1.00 & -0.01 \\
\hline$\%$ of household with electricity & 1.00 & 1.00 & 1.00 & 0.00 \\
\hline$\%$ of household with own water source & 0.81 & 0.81 & 0.80 & 0.00 \\
\hline$\%$ of household with own radio & 0.42 & 0.42 & 0.44 & -0.02 \\
\hline$\%$ of household with own television & 0.94 & 0.94 & 0.97 & -0.03 \\
\hline$\%$ of household with own computer & 0.13 & 0.13 & 0.18 & -0.05 \\
\hline$\%$ of household with own mobile phone & 0.88 & 0.87 & 0.95 & $-0.08 * *$ \\
\hline Owns mobile phone (unit) & 1.83 & 1.79 & 2.24 & $-0.45^{* * *}$ \\
\hline$\%$ of household with owns internet access & 0.29 & 0.27 & 0.45 & $-0.17 * * *$ \\
\hline \multicolumn{5}{|l|}{ Agricultural assets (million Rp) } \\
\hline Transportation asset (e.g. motorbike) & 8.42 & 8.61 & 6.81 & 1.79 \\
\hline Production asset (e.g. water pump, sprayer) & 1.49 & 1.44 & 1.95 & -0.51 \\
\hline Storage asset (e.g. storage house) & 2.05 & 1.46 & 7.08 & $-5.62 * * *$ \\
\hline Owned land (ha) & 0.56 & 0.57 & 0.49 & 0.08 \\
\hline \multicolumn{5}{|l|}{ Location } \\
\hline Distance to nearest asphalt road (km) & 0.19 & 0.20 & 0.16 & 0.03 \\
\hline Distance to nearest local market (km) & 3.64 & 3.64 & 3.63 & 0.01 \\
\hline Distance to nearest urban market $(\mathrm{km})$ & 20.54 & 20.21 & 23.35 & $-3.14 * *$ \\
\hline Elevation $(\mathrm{m})$ & 196.82 & 185.51 & 293.04 & $-107.5^{* * *}$ \\
\hline
\end{tabular}

Notes: ${ }^{1}$ Based on t-test: ${ }^{* * *},{ }^{* *},{ }^{*}$ indicate statistical significance at the $1 \%, 5 \%$ and $10 \%$ levels, respectively.

\section{Farm Characteristics}

This section focuses on farm characteristics in order to explore how adopters of new horticultural crops differ from non-adopters. Existing literature shows that farm characteristics, including farm size, land tenure, and cost of technologies, are important factors influencing agricultural technology adoption (Feder et al. 1985; Rogers, 2003; Doss, 2006). Table 2 shows a comparison of farm characteristics of adopters and non-adopters of new horticultural crops and highlight the practices of production, input use and harvesting. 
Table 2. Comparison of farm characteristics for adopters and non-adopters of new horticultural crops

\begin{tabular}{|c|c|c|c|c|}
\hline \multirow{2}{*}{ Farm Characteristics } & $\begin{array}{l}\text { All Samples } \\
(\mathrm{n}=960)\end{array}$ & $\begin{array}{c}\text { Non-adopters } \\
(\mathrm{n}=859)\end{array}$ & $\begin{array}{c}\text { Adopters } \\
(\mathrm{n}=101)\end{array}$ & \multirow[t]{2}{*}{ Diff' $^{1}$} \\
\hline & Mean & Mean & Mean & \\
\hline \multicolumn{5}{|l|}{ Production characteristics } \\
\hline Owned-farmed land (ha) & 0.52 & 0.52 & 0.45 & 0.08 \\
\hline Farmed land (ha) & 0.76 & 0.76 & 0.82 & -0.06 \\
\hline$\%$ of land that is rented & 13.63 & 12.54 & 22.89 & $-10.3 * * *$ \\
\hline$\%$ of land that is irrigated & 56.27 & 56.92 & 50.71 & 6.21 \\
\hline Gini index & 0.13 & 0.12 & 0.18 & $-0.06 * * *$ \\
\hline Sympson diversification index & 0.45 & 0.44 & 0.61 & $-0.17 * * *$ \\
\hline Number of crops planted & 3.06 & 2.91 & 4.38 & $-1.47 * *$ \\
\hline Number of horticultural crops planted & 0.91 & 0.76 & 2.15 & $-1.39 * * *$ \\
\hline$\%$ of households where spouse managed at least one crop & 0.28 & 0.28 & 0.25 & $0.03^{* * *}$ \\
\hline$\%$ of households having production contract with buyer & 0.06 & 0.06 & 0.03 & 0.03 \\
\hline \multicolumn{5}{|l|}{ Production costs } \\
\hline$\%$ of households using hired labor & 0.86 & 0.85 & 0.94 & $-0.10 * * *$ \\
\hline Purchased seed costs (million Rp) & 0.83 & 0.75 & 1.46 & $-0.70 * * *$ \\
\hline Organic fertilizer costs (million Rp) & 0.27 & 0.26 & 0.28 & $-0.02 * * *$ \\
\hline Chemical fertilizer costs (million Rp) & 1.94 & 1.90 & 2.27 & -0.37 \\
\hline Other fertilizer costs (million Rp) & 0.13 & 0.13 & 0.16 & -0.03 \\
\hline Chemical pesticide costs (million Rp) & 0.89 & 0.82 & 1.47 & -0.65 \\
\hline Bio-pesticide costs (million Rp) & 0.01 & 0.00 & 0.03 & $-0.02 * * *$ \\
\hline Tractor hire or animal costs (million $\mathrm{Rp}$ ) & 0.63 & 0.64 & 0.49 & $0.15^{* * *}$ \\
\hline Other crop input costs (million Rp) & 2.76 & 2.78 & 2.62 & 0.16 \\
\hline Total input costs (million Rp) & 7.44 & 7.28 & 8.78 & -1.50 \\
\hline \multicolumn{5}{|l|}{ Harvesting characteristics } \\
\hline Harvest value (revenue in million $\mathrm{Rp}$ ) & 32.13 & 31.96 & 33.57 & -1.61 \\
\hline Harvest value (revenue) per hectare & 46.50 & 45.63 & 53.92 & $-8.29 *$ \\
\hline Harvest value (revenue) from horticultural crops (million $\mathrm{Rp}$ ) & 4.90 & 3.94 & 13.11 & $-9.17 * * *$ \\
\hline Harvest value (revenue) from horticulture per hectare & 16.35 & 14.01 & 24.53 & $-10.52 * * *$ \\
\hline Harvest value (revenue) from staple food crops (million Rp) & 22.14 & 22.66 & 17.66 & 5.01 \\
\hline$\%$ sold value from horticultural crops & 18.55 & 15.45 & 44.25 & $-28.80 * *$ \\
\hline$\%$ sold value from staple food crops & 64.59 & 67.43 & 41.00 & $26.43 * * *$ \\
\hline$\%$ of households selling crop "in ground" & 0.44 & 0.44 & 0.47 & $-0.02 * * *$ \\
\hline $\begin{array}{l}\% \text { of household selling using tebasan systems for horticultural } \\
\text { crops }\end{array}$ & 0.14 & 0.13 & 0.23 & -0.10 \\
\hline
\end{tabular}

Note: ${ }^{1}$ Based on t-test: $* * *, * *, *$ indicate statistical significance at the $1 \%, 5 \%$ and $10 \%$ levels, respectively.

First, in terms of production characteristics, on average, for the entire sample, households farmed approximately 0.76 hectares, of which 0.52 hectares was owned farmed land (Table 2). The average farm size was not statistically different between adopters and non-adopters at 0.82 hectares and 0.76 hectares, respectively. Similarity of farm size suggests that most households in this study can be considered small-scale farmers, on average. Compared to current National Agricultural Census (Sensus Pertanian, 2013) data, $45.4 \%$ of farm households in this study had less than 0.5 ha of land compared to the average for all Indonesian farmers (55.9\%) (BPS, 2013).

New horticultural crop adopters rented significantly more land than non-adopters. As explained above, approximately $8.0 \%$ of the land used for planting new horticultural crops was rented land. In addition, in terms of diversification, farm household adopters were more diversified in the farming system. Adopters were also more diversified within horticultural crop production. This suggests that they tend to allocate land 
to different horticultural crops, presumably to meet continuous growing demand from markets for multiple horticultural products.

Another difference between adopters and non-adopters of new horticultural crops in Indonesia is that spouses of adopters in this study had less engagement with the household's horticultural crop production. This finding is contrast to recent studies, which highlight that women play a crucial role in horticultural development (e.g. Maertens \& Swinnen, 2012; Virchow et al. 2015). For example, Maertens and Swinnen (2012) found that women benefit more and more directly engage to labour market as hired employees in Senegalese horticultural chains. This finding also indicates that it is important to consider whether there is a need for specific horticultural production training programs for women in order to improve their skills. However, the study does not know whether women would want to participate in horticultural production training programs - they may well be choosing not to participate in this aspect of the household agricultural enterprise for reasons other than not having the relevant skills.

Second, in terms of production costs. Table 2 shows production costs of farming activities. Total input costs were not significantly different between new horticultural crop adopters and non-adopters. However, the average total input costs of adopting farmers were relatively higher than non-adopting farmers, 8.78 versus 7.28 million Rupiah, respectively. Both new horticultural crop adopters and non-adopters spent relatively the same amount of money on chemical inputs, such as fertiliser and pesticide.

Adopters used more hired labour and spent more on purchasing seeds compared to non-adopters (Table 2). Another interesting difference was that new horticultural crop adopters spent slightly more on organic fertiliser and bio-pesticide. This is in line with initial information gathered from the scoping study interview that there were an increasing number of horticultural producers concerned about food safety and that there is growing market demand in Indonesia for horticultural products that are organic or grown using low input spray techniques (Minot et al. 2015; Wahida, 2015).

Third, in terms of harvesting characteristics, on average, there were no significant differences in the total value of crops harvested and sold (or crop revenue) by households. However, the average value of crops produced per hectare was significantly higher for adopters of horticultural crops (Table 2). This is perhaps not surprising considering that value of horticultural crops per hectare is generally higher than staples, however, increased revenue may be offset by relatively higher costs of seed and fertiliser per hectare as discussed in the previous section paragraph.

In terms of trader-harvester contracts or tebasan systems (defined as a contract harvesting system whereby crops are sold prior to harvest by the farmer to a middleman (trader), who employs contract workers to complete the harvest (Manning, 1988; Naylor, 1992)), no statistically significant difference were found between adopters and non-adopters of new horticultural crops (Table 2). However, adopting farmers were more likely to enter into such a contract than non-adopting farmers as indicated by percentage of farm households with experiencing sold in tebasan system for horticultural products at 23 and $13 \%$, respectively. Based on interviews with key informants in the study areas, farmers chose to enter trader-harvester contracts due to constraints regarding hired labour to complete harvest and conduct the postharvest handling. Another reason for entering this contract is to receive payment from the buyer (trader) before harvest or upon delivery (Wahida, 2015).

\section{Institutional Factors}

Existing literature shows that institutional factors, such as producer organisation involvement and access to information were considered important variables that may increase rates of adoption (Feder et al. 1985; Doss, 2006). Table 3 presents a comparison of institutional factors.

New horticultural crop adopters had a significantly higher rate of participation in extension programs, such as horticultural production and farmer field of school of good agricultural practices (FFS GAP) for horticultural crop training programs, as compared to non-adopters. The training programs include assistance on how to produce fruits or vegetables in order to meet food safety standards. This suggests that a lack of information and knowledge about horticultural farming practices could be an obstacle to the adoption of horticultural crops. Furthermore, a significantly higher proportion of adopters were involved in farmer groups or cooperatives. This involvement perhaps offers opportunities for training programs including training related to horticultural crop production. In 
addition, previous studies show that involvement in producer groups could influence farmers to adopt a new agricultural technology (Matuschke \& Qaim, 2009; Abebaw \& Haile, 2013).

\section{Income Activities}

This section provides details on the household income characteristics of adopters and non-adopters of new horticultural crops. It is important to explore the contribution of each source of income in order to consider possible economic benefits of agricultural technology adoption. Table 4 presents a comparison of income sources of adopters and non-adopters, including farm and non-farm activities. In this study, farm activities include income from growing agricultural crops (horticulture, estate and other staple food crops), livestock activities, and aquaculture activities. Nonfarm activities include all other activities which garner household income, as shown in Table 4.
For both adopters and non-adopters, the main source of income for both groups was from agricultural activities. No statistically significant differences were found between the net household incomes new horticultural crop adopters and non-adopters (Table 4). The share of total net household income from agriculture was similar for both groups. The only significant difference was that recent horticultural adopters had a higher net income from horticulture crops.

Both adopters and non-adopters of new horticultural crops also generate income from non-farm activities: trading and enterprises, agricultural wage labour, nonagricultural employment, pension, remittances from family members, assistance programs, and other sources of income (Table 4). Overall, the average household income from these activities was not statistically different across the two groups. Interestingly, no farm households in this study indicated that they received assistance from programs, such as subsidies from the Indonesian government or other non-governmental and civil society organisations.

Table 3. Comparison of institutional characteristics and income sources for adopters and non-adopters of new horticultural crops

\begin{tabular}{|c|c|c|c|c|}
\hline \multirow{2}{*}{ Characteristics } & $\begin{array}{l}\text { All Samples } \\
(\mathrm{n}=960)\end{array}$ & $\begin{array}{l}\text { Non-adopters } \\
\quad(\mathrm{n}=859)\end{array}$ & $\begin{array}{c}\text { Adopters } \\
(\mathrm{n}=101)\end{array}$ & \multirow{2}{*}{$\operatorname{Diff}^{1}$} \\
\hline & Mean & Mean & Mean & \\
\hline \multicolumn{5}{|l|}{ Institutional characteristics } \\
\hline $\begin{array}{l}\text { Received information about horticultural production from } \\
\text { extension officers }(1 / 0)\end{array}$ & 0.19 & 0.16 & 0.43 & -0.27 \\
\hline $\begin{array}{l}\text { Received information about staple production from extension } \\
\text { officers }(1 / 0)\end{array}$ & 0.55 & 0.54 & 0.67 & $-0.14 * * *$ \\
\hline Participated in FFS GAP/GHP for horticultural crops $(1 / 0) \mathrm{a}$ & 0.09 & 0.08 & 0.16 & -0.08 \\
\hline Participated in FFS ICM for staple food crops $(1 / 0) b$ & 0.36 & 0.35 & 0.44 & $-0.09 * *$ \\
\hline Participated in FFS IPM $(1 / 0) c$ & 0.42 & 0.41 & 0.53 & $-0.13 *$ \\
\hline Membership in farmer group/cooperative $(1 / 0)$ & 0.78 & 0.77 & 0.89 & $-0.12 * * *$ \\
\hline Membership in water use association (1/0) & 0.32 & 0.32 & 0.30 & 0.02 \\
\hline Membership in women farmer's group (1/0) & 0.04 & 0.04 & 0.10 & -0.06 \\
\hline Membership in gotong royong ( 1 if yes, 0 otherwise) & 0.11 & 0.11 & 0.14 & -0.03 \\
\hline
\end{tabular}

Note: ${ }^{1}$ Based on t-test: $* * *, * *, *$ indicate statistical significance at the $1 \%, 5 \%$ and $10 \%$ levels, respectively. a) Farmer Field School-Good Agricultural Practices/Good Handling Practices, b) Farmer Field School-Integrated Crop Management, c) Farmer Field School-Integrated Pesticide Management 
Table 4. Comparison of income sources for adopters and non-adopters of new horticultural crops

\begin{tabular}{lcccc}
\hline \multirow{2}{*}{\multicolumn{1}{c}{ Income sources (Rp million) }} & $\begin{array}{c}\text { All Samples } \\
(\mathrm{n}=960)\end{array}$ & $\begin{array}{c}\text { Non-adopters } \\
(\mathrm{n}=859)\end{array}$ & $\begin{array}{c}\text { Adopters } \\
(\mathrm{n}=101)\end{array}$ & \multirow{2}{*}{ Diff $^{1}$} \\
\cline { 2 - 4 } & Mean & Mean & Mean & \\
\hline Net household income & 42.39 & 42.72 & 39.55 & 3.18 \\
Net household income, excluding imputed income & 35.27 & 35.55 & 32.89 & 2.65 \\
Net household income per capita & 11.99 & 12.20 & 10.18 & 2.02 \\
Net income from agriculture & 21.99 & 22.04 & 21.52 & 0.53 \\
Net income from agriculture, excluding imputed income & 14.86 & 14.87 & 14.86 & 0.00 \\
\% of net household income from agriculture & 57.01 & 57.16 & 55.73 & 1.43 \\
Net income from horticulture & 2.65 & 2.18 & 6.69 & $-4.51^{* * *}$ \\
Net income from staple food crops & 13.32 & 13.65 & 10.49 & 3.16 \\
Net income from other crops (e.g. sugarcane) & 3.14 & 3.27 & 2.04 & 1.23 \\
Net income from livestock and aquaculture & 2.86 & 2.92 & 2.30 & 0.62 \\
Gross income from non-horticulture & 26.05 & 27.04 & 17.65 & $9.40^{* * *}$ \\
Net income from remittance & 1.35 & 1.44 & 0.59 & 0.86 \\
Net income from agricultural wage & 0.89 & 0.84 & 1.34 & -0.50 \\
Net income from non-agricultural wage & 6.48 & 6.64 & 5.09 & 1.55 \\
Net income from trading and enterprises & 9.67 & 9.63 & 10.04 & -0.42 \\
Net income from assistance programs & 0.00 & 0.00 & 0.00 & 0.00 \\
\hline
\end{tabular}

Note: ${ }^{1}$ Based on t-test: $* * *, * *, *$ indicate statistical significance at the $1 \%, 5 \%$ and $10 \%$ levels, respectively.

\section{Managerial Implications}

Indonesian smallholder farmers have an opportunity to respond to the rapid growth of high value horticultural market by adopting new horticultural crops such as fruits and vegetables. To address the smallholder farmers' constraints regarding horticultural crop adoption, therefore, more intensive support is needed to promote greater participation of Indonesian smallholder farmers in horticultural value chains. This can be achieved, for example, by enhancing communication between agricultural extension agents and farmers to potentially improve information and training about horticultural crop production. In addition, smallholder farmers need to be encouraged to participate in producer organisations, such as a farmer group or cooperative.

\section{CONCLUSIONS AND RECOMMENDATIONS}

\section{Conclusions}

This study identified relatively low adoption rates $(10 \%)$ of new horticultural crops amongst the 960 selected farm households from six districts across Java Island. In relation to the relatively low adoption rate of horticultural crops, results of basic descriptive statistical analysis suggest that existing householdlevel characteristics may be constraining factors for farmers to adopt new horticultural crops. Non-adopters are relatively older, less educated, and less diversified in their farming systems. They are also less likely to own mobile phones and to have Internet access. In general, they also lack information and training with regards to horticultural crop production methods. In addition, results show that many non-adopters were not participating in producer organisations, such as a farmer group or cooperatives - in Indonesia, these types of organisations are often used to disseminate information about new technologies as well as the technology, including seeds. Another finding of this study revealed significant difference between adopters and nonadopters in terms of non-horticultural income.

\section{Recommendations}

Future research may be extended using rigorous econometric analysis to examine the determinants of horticultural crop adoption among farmers in Indonesia and adding other important characteristics such as technology attributes. In addition, further research may also be conducted to analyse the impact of farmer adoption of horticultural crops on farm household welfare. 


\section{ACKNOWLEDGEMENTS}

The study was made possible by funding from the Australian Centre for International Agriculture Research (ACIAR). I gratefully acknowledge the support from the Centre for Agrifood Policy and Agribusiness Studies (CAPAS), the University of Padjadjaran in Bandung, Indonesia in survey implementation, Ms. Wahida in the Center of Global Food and Resource at the University of Adelaide, Australia for insight in pre-survey development and all 18 enumerators in data collection.

\section{REFERENCES}

Abebaw D, Haile MG. 2013. The impact of cooperatives on agricultural technology adoption: Empirical evidence from Ethiopia. Food Policy 38:82-91.

Babatunde RO, Qaim M. 2010. Impact of off-farm income on food security and nutrition in Nigeria. Food Policy 35(4):303-311.

Black K. 2009. Business statistics: Contemporary decision making. US: John Wiley \& Sons.

BPS. 2013. Laporan Hasil Sensus Pertanian 2013 (report of the national agricultural census 2013). Jakarta: Badan Pusat Statistik.

Daryanto A et al. 2015.Transformasi Struktural Usahatani dan Petani Indonesia, Analisis Tematik ST2013 Subsektor. Jakarta: Badan Pusat Statistik.

Doss CR. 2006. Analyzing technology adoption using microstudies: Limitations, challenges, and opportunities for improvement. Agricultural Economics 34(3):207-219.

Feder G, Just RE, Zilberman D. 1985. Adoption of agricultural innovations in developing countries: A survey. Economic Development and Cultural Change 33 (2):255-298.

Foster AD, Rosenzweig MR. 2010. Microeconomics of technology adoption. Annual Review of Economics 2(1).

Hughes JdA, Keatinge J. 2012. The nourished millennium: How vegetables put global goals for healthy, balanced diets within reach', in R Holmer, G Linwattana, P Nath \& J Keatinge (eds), High Value Vegetables in Southeast Asia: Production, Supply and Demand (SEAVEG2012), AVRDCThe World Vegetable Center, Chiang Mai, Thailand, pp. 11-26.

Jack BK. 2011. Constraints on the adoption of agricultural technologies in developing countries', White paper, Agricultural Technology Adoption Initiative. Boston: J-PAL (MIT) and Berkeley: CEGA (UC Berkeley).

Joshi P, Joshi L, Birthal PS. 2006. Diversification and its impact on smallholders: Evidence from a study on vegetable production. Agricultural Economics Research Review 19(2):219-236.

Krishnan P, Patnam M. 2013. Neighbors and extension agents in Ethiopia: Who matters more for technology adoption?. American Journal of Agricultural Economics 96(1): 308-327.

Maertens M, Minten B, Swinnen J. 2012. Modern food supply chains and development: Evidence from horticulture export sectors in Sub-Saharan Africa. Development Policy Review 30(4): 473497.

Matuschke I, Qaim M. 2009. The impact of social networks on hybrid seed adoption in India. Agricultural Economics 40(5): 493-505.

Midmore DJ, Poudel DD. 1996. Asian vegetable production systems for the future. Agricultural Systems 50(1): 51-64.

Minot $\mathrm{N}$ et al. 2015. Urban shopping patterns in Indonesia and their implications for small farmers. Bulletin of Indonesian Economic Studies 51(3): 375-388.

Poudel DD, Midmore DJ, Hargrove WL. 1998.An analysis of commercial vegetable farms in relation to sustainability in the uplands of Southeast Asia. Agricultural Systems 58(1): 107-128.

Reardon T et al. 2015.Transformation of the Indonesian agrifood system and the future beyond rice: A special issue. Bulletin of Indonesian Economic Studies 51(3): 369-373.

Reardon T et al. 2014.Urbanization, Diet Change, and Transformation of Food Supply Chains in Asia. East Lansing: MI.

Rogers EM. 2003. Diffusion of innovations, 5th edition, NY:Simon and Schuster.

Roy D, Thorat A. 2008. Success in high value horticultural export markets for the small farmers: The case of Mahagrapes in India.World Development 36(10):1874-1890.

Schipmann C, Qaim M. 2009. Modern supply chains and product innovation: How can smallholder farmers benefit? in 27th IAAE Conference, Beijing, pp. 16-22.

Suprehatin. 2016. Adoption of high value horticultural crops in Indonesia: determinants and impacts [PhD thesis]. Adelaide: The University of 
Adelaide.

Toiba H, Umberger WJ, Minot N. 2015. Diet transition and supermarket shopping behaviour: Is there a link?. Bulletin of Indonesian Economic Studies 51(3): 389-403.

Virchow D et al. 2015. Small-scale vegetable production and marketing systems for food and nutrition security: Challenges and prospects for Southeast Asia', in Proceedings of the Regional Symposium on Sustaining Small-Scale Vegetable
Production and Marketing Systems for Food and Nutrition Security (SEAVEG2014), 25-27 February 2014, Bangkok, Thailand. AVRDCThe World Vegetable Center, pp. 432-441.

Wahida. 2015. Food system transformation in Indonesia: factors influencing demand and supply for alternative pest management farming systems [PhD thesis]. Adelaide: The University of Adelaide. 